\title{
Modeling Streamflow and Sediment Yield with Determination of Soil Erosion Prone Areas by Using the SWAT Model
}

ERKAN KARAKOYUN ( $\nabla$ e.karakoyun@alparslan.edu.tr)

Mus Alparslan University: Mus Alparslan Universitesi https://orcid.org/0000-0003-2821-9103

Nihat Kaya

Firat University: Firat Universitesi

\section{Research Article}

Keywords: Sediment yield, Streamflow, SWAT Model, Soil erosion, Euphrates-Tigris basin, Watershed management

Posted Date: February 15th, 2022

DOI: https://doi.org/10.21203/rs.3.rs-1338298/v1

License: (c) (1) This work is licensed under a Creative Commons Attribution 4.0 International License.

Read Full License 


\section{Modeling Streamflow and Sediment Yield with Determination of Soil Erosion Prone Areas by Using the SWAT Model}

Erkan Karakoyun $^{1 *}$, Nihat Kaya ${ }^{2}$

${ }^{1}$ Faculty of Engineering and Architecture, Muş Alparslan University, Muş 49250, Turkey

${ }^{2}$ Faculty of Engineering, Department of Civil Engineering, Firat University, Elazig 23119, Turkey

*Corresponding author: Erkan Karakoyun

Mailing address: Faculty of Engineering and Architecture,

Muş Alparslan University,

49250 Muş, Turkey

Tel.: +90-436-249-4949/1964

E-mail address: e.karakoyun@alparslan.edu.tr 


\section{ABSTRACT}

In this study, the Soil and Water Assessment Tool (SWAT) was used to estimate the streamflow, sediment yield, and the identification of soil erosion prone areas at the subwatershed scale to enrich the water management practices. The upper part of the EuphratesTigris basin called as Murat River basin was selected as a study area. Nash-Sutcliffe Efficiency (NSE), coefficient of determination (R2), and percent bias (PBIAS) were used for the assessment of the model performance with the observed data at two gage stations located on the watershed, E21A074, and E21A077. The Modified Universal Soil Loss Equation was used in the SWAT model in order to predict sediment yield and soil erosion. Sediment Delivery Ratio was also computed to identify its relationship with sediment yield at the subwatershed scale. NSE, R2, and PBIAS for monthly streamflow prediction were calculated as $0.71,0.72$, and -11.6 in the calibration period, as $0.77,0.79$, and -9.1 in the validation period, at the station E21A077, respectively. Daily simulation the results of NSE, R2, and PBIAS were calculated as $0.56,0.57$, and -15 in the calibration period, while $0.55,0.56$, and 1.2 , respectively, in the validation period at the station E21A074. The statistical results for monthly sediment yield calibration and validation were calculated as follows: 0.75 and 0.80 for NSE, 0.76 and 0.84 for R2, -0.9 and 12.2 for PBIAS from the station E21A074. 32\% area of the total watershed is under severe and very severe soil erosion conditions. Most of the soil erosion occurred at the barren land use and in the sub-watersheds with a slope greater than $25 \%$. Overall, the SWAT model satisfactorily simulated the streamflow and sediment yield at the Murat River basin which may help the researchers in water resource management. 
Key Words: Sediment yield, Streamflow, SWAT Model, Soil erosion, Euphrates-Tigris basin, Watershed management 


\section{INTRODUCTION}

Sedimentation is the main problem for dams and hydraulic structures which results in the reduction of the dam's usable storage volume in the determination of capacity and operation. (Morris and Fan 1998). Each year reservoirs around the world lose their storage volume by 0.5-1\% (Mahmood 1987). River flow and runoff water are the primary sources carrying the sediments into the reservoirs (Ezz-Aldeen et al. 2018). The sedimentation occurring in the reservoir affects the water quality both chemically and physically (Alemayehu et al. 2014). Chemically, sediments act as a distribution mechanism for particular pollutants degrading the water quality within a reservoir. Physically, sedimentation reduce the useful life of the reservoir (Juracek and Stiles 2003). In Turkey, 84 million tons of soil is carried in the Euphrates-Tigris basin, out of 154 million total soil erosion (CEM 2018).

Soil erosion occurs mainly on erodible soils, high terrain slopes, and intensive rainfall (Beskow et al. 2009). But not all sediment particles eroded from the watershed are carried out to the outlet as they are trapped upstream. A part of the eroded material carried to the watershed outlet is referred to as sediment yield (Walling 1983; Dutta and Sen 2017) that is an important variable to design hydraulic structures. Sediment yield is usually not obtained with direct measurements but can be predicted by using sediment delivery ratio (SDR) (Ouyang and Bartholic 1997). SDR is an important variable for environmental protection and sustainable management in the control of sedimentation and soil erosion (Ouyang and Bartholic 2005). SDR is calculated as the ratio of sediment yield at the watershed outlet and the gross erosion in the watershed. Therefore, sediment yield and soil erosion become a function of sedimentation to specify the lifetime of dam (Dutta 2016). Soil erosion can be 
caused to agricultural, environmental, and economic problems (Pimentel et al. 1995; Portenga and Bierman 2011; Wu and Chen 2012; Briak et al. 2016). Moreover, because of climate changing and human interference, soil erosion has become a more challenging issue (Zare et al. 2017). Efforts are needed to preserve soil and water resources at the sub-basin scale to minimize the negative impact of soil erosion on the environment.

In order to estimate accurate and reliable streamflow, sediment yield, and soil erosionprone areas, some hydrological models are used. In parallel with the development of computer technology and Geographic Information Systems, basin modeling studies have also been developed. These models are used effectively to estimate water quality, sediment and streamflow, the effects of climate, and land-use changes (Van Liew and Mittelstet 2018). The Soil and Water Assessment Tool (SWAT) developed by Arnold et al. (1998) is a physical based hydrological model that are used widely in literature for different purposes. Several researchers have been studied with SWAT for simulating runoff (Alipour and Hosseini 2018; Ang and Oeurng 2018; Jakada and Chen 2020), sediment yield (Xu et al. 2009; RodríguezBlanco et al. 2016), and water quality (Qi et al. 2020; Abbaspour et al. 2007); determine soil erosion areas (Vigiak et al. 2015; Dutta and Sen 2017; Daramola et al. 2019), in different watersheds. Additionally, the model has been applied to the impact of climate change (Zhang et al. 2014); land use, and land cover changes; (Abellan et al. 2019; Worku et al. 2017). The use of the SWAT model has been increasing for its successful prediction and popularity selected for this study.

Several studies have been conducted by using the SWAT model around the world, but these studies are limited in Turkey (Akiner and Akkoyunlu 2012; Cuceloglu et al. 2017; 
Guzel 2010; Yıldırımer 2018; Peker and Sorman 2021) especially in the Euphrates-Tigris basin in Turkey. Nearly a quarter of soil erosion and half of the sediment yield of Turkey occur in this basin (CEM 2018) which lead the study to become more important. The SWAT model has been used in this study to simulate the hydrological models and identify the soil erosion prone areas on the upper part of the Euphrates-Tigris basin. Besides, the detailed objectives of this study are: (1) evaluation of SWAT model to estimate sediment yield and streamflow on monthly time periods, (2) also compare the prediction of streamflow with daily period, (3) determine soil erosion prone areas and properly prioritize on the study watershed to mitigate the erosion on negative affect, (4) classified the SDR and sediment yield on sub-watershed which is a critical parameters for sedimentation problems (5) and determine the relationships between rainfall, runoff, sediment yield and soil erosion on the watershed.

\section{MATERIALS AND METHODS}

\subsection{Study Area}

The study area, called as Murat River basin, is located on the upper part of the EuphratesTigris basin covering $22.6 \%$ of the country area (Fig. 1). The length of the Murat river is 720 $\mathrm{km}$ and merge with the Karasu River then generate the Euphrates River. Data from two gauging stations (E21A074, 39 $02^{\prime} \mathrm{N} ; 41^{\circ} 31^{\prime} \mathrm{E}$ and $\left.\mathrm{E} 21 \mathrm{~A} 077,39^{\circ} 13^{\prime} \mathrm{N} ; 42^{\circ} 10^{\prime} \mathrm{E}\right)$ were used to perform the SWAT model located on Murat River basin (Fig. 1). The area of the Murat River basin is $17865 \mathrm{~km} 2$ with an elevation range between $1239-4033 \mathrm{~m}$. The watershed is divided into five slope classes. $21 \%$ of the watershed area has a slope greater than $25 \%$. The yearly average precipitation of the studied watershed is $693 \mathrm{~mm}$ with $257 \mathrm{~mm}$ surface runoff. 
The maximum temperature was recorded in the studied period (2005-2013), in August 2006 as $38.1^{\circ} \mathrm{C}$ and the minimum temperature in January 2012 as $-33.7^{\circ} \mathrm{C}$. The winter is generally snowy where snowmelt is the main source feeding the river. Since the watershed is mountainous, urbanization is limited. Nearly half of the watershed is covered by pasture.

\subsection{SWAT Model Desription}

ArcSWAT is a free software program in which SWAT is integrated with the ArcView Geographic Information System(GIS). The SWAT is developed by the United States Department of Agriculture (USDA)-Agricultural Research Service (ARS) as a hydrological model to estimate the impact of land management practices on the sediment yield, water, nutrients and water quality in the large basins (Arnold et al. 1998). The SWAT is a computationaly effective physical based continuous time model that can perform on a daily to yearly time interval. The Digital Elevation Model (DEM) is used in the SWAT model to delineate the basin boundary and to divide the basin into sub-basins (Arnold et al. 2012). Further, each sub-basin is subdivided into the hydrological response units (HRUs) which consist of similar soil, land use, and slope properties (Arnold et al. 2012). The hydrological cycle in the SWAT model is based on the water balance Equation (Eq.1) (Neitsch et al. 2005).

$$
S W_{t}=S W_{0}+\sum_{n=1}^{t}\left(R_{\text {day }}-Q_{\text {surf }}-E_{a}-W_{\text {seep }}-Q_{g w}\right)
$$

Where $S W_{t}$ is the soil water content (mm), $S W_{0}$ is the initial soil water content (mm), $R_{d a y}$ is the precipitation (mm), $Q_{\text {surf }}$ is the surface runoff (mm), $E_{a}$ is the evapotranspiration $(\mathrm{mm}), W_{\text {seep }}$ is the amount of water entering the vadose zone from the soil profile (mm), $Q_{g w}$ is the return flow $(\mathrm{mm})$ and $t$ is the time. 
The SWAT model is widely used to predict the sediment yield in previous studies (Tesema and Leta 2020; Gull et al. 2017). Runoff would be the critical factor with transporting capacity for controlling sediment yield (Mutchler et al. 1988). Modified Universal Soil Loss Equation (MUSLE) is used to predict the sediment yield and soil erosion for each sub-basin (Williams 1975) as given by Equation 2.

$$
\text { Sed }=11.8 *\left(Q_{\text {surf }} * q_{\text {peak }} * \text { area }_{h r u}\right)^{0.56} K_{U S L E} * C_{U S L E} * P_{U S L E} * L S_{U S L E} * C F R G
$$

where Sed is the sediment yield on a given day (tons), $Q_{\text {surf }}$ is the surface runoff volume $(\mathrm{mm} / \mathrm{ha}), q_{\text {peak }}$ is the peak runoff rate $\left(\mathrm{m}^{3} / \mathrm{s}\right)$, area $_{\text {hru }}$ is the area of HRU (ha), $K_{U S L E}$ is the USLE soil erodibility factor, $C_{U S L E}$ is the USLE soil cover factor, $P_{U S L E}$ is the USLE support practice factor, $L S_{U S L E}$ is the topographic factor, slope length and slope steepness as dimensionless factor and $C F R G$ is the coarse fragment factor.

The peak runoff rate is defined by SWAT model as following Equation.

$$
Q_{\text {peak }}=\frac{A * Q_{\text {surf }} * \text { Area }}{360 * t_{\text {conc }}}
$$

where $Q_{\text {peak }}$ is the peak runoff rate $\left(\mathrm{m}^{3} / \mathrm{s}\right), A$ is the fraction of total rainfall that occurs during the time of concentration, Area is the HRU area (ha), $t_{\text {conc }}$ is the time of concentration (hr).

\subsection{SWAT Model Inputs}

SWAT is a physically-based model that requires a great deal of input data such as topographic, soil properties, land use/cover, hydrological, and meteorological data. In this study, SWAT 2012 with an ArcGIS 10.7 (Esri 2019) interface was used to perform the SWAT model. The DEM data was obtained from ASTER Global Digital Elevation Model 
V3 with $30 \mathrm{~m}$ spatial resolution (NASA, 2019). Before adding the DEM into the ArcSWAT, the edited DEM was projected to WGS84 UTM Zone-38N as a study area location. Then, the watershed was delineated to analyze the drainage pattern of the land surface and then subdivided into 143 sub-watersheds. The elevation range found for the watershed varies from 1239 to $4030 \mathrm{~m}$ as seen in Fig. 2a.

The land use/cover map was obtained from the CORINE 2012 Land Cover datasets (CLC 2012) with a $100 \mathrm{~m}$ resolution. Since the studied period was obtained between 2005-2013, the year of land cover data was chosen as 2012 to better represent the calibration/validation period. The dominant land cover was observed as a pasture with a portion of $47.43 \%$ and agricultural land (26.48\%), barren (22.91\%), water (1.41\%), residential (1.02\%), and wetland $(0.42 \%)$ as seen in Fig. 2b. The soil map was obtained from the HWSD database of the Food and Agriculture Organization (FAO 2012). The grid-based soil data obtained from the DSMW database was added into the model in the same projection as the digital elevation model and land use/land cover data after adding the properties of the DSMW soils to the model database file. According to the FAO's soil classification system, Eutric Cambisols (Be115-2-3), Lithosols-Eutric Cambisols (I-Be-c), Lithosols-Calcaric Regosols-Calcic Xerosols (I-Rc-Xk-c), Haplic Kastanozems (Kh1-2ab), Calcic Kastanozems (Kk16-2b), and Haplic Xerosols (Xh31-3a) was defined in the study area (Fig. 2c). The whole watershed was categorized into five slope classes using the ArcSWAT interface (Fig. 2d). Then all the maps, land use/cover, soil, and slope, were overlaid to create the HRU's. Since the studied watershed is snow dominated mountainous, ten elevation bands were added to increase the model accuracy. The purpose of this process is to enable the model to simulate snowfall and 
snowmelt separately for each elevation band by taking into account the changes in precipitation and temperature depending on the altitude in each sub-basin (Abbaspour et al. 2007).

Due to the lack of available datasets (such as relative humidity, wind speed, solar radiation) for the study are, globally available weather data were used for SWAT modeling. Climate Forecast System Reanalysis (CFSR) by the National Centers for Environmental Prediction was used for climate data. Twelve points were detected for obtaining climate data from CFSR in the studied area (Fig. 2a). The observation data, suspended sediment, and discharge were obtained from Turkish State Hydraulics Works (DSI). Since the sediment data were not collected periodically by DSI, the LOADEST estimator, version 2012 (Runkel et al. 2004) was used to convert sediment data to monthly sediment load. After entering all input parameters into the interference, the SWAT model was set and run on a daily and monthly period for the years between 2005-2013 that was set one year as a warm-up period.

\subsection{Sensitivity Analysis, Model Calibration and Validation}

Several parameters can be used for calibration and validation procedures. However, some parameters are affecting the targeted variable more than the other parameters, defined as a sensitivity analysis (Panda et al. 2021). SWAT Calibration Uncertainty Procedure (SWATCUP) program was used to compare flow and sediment prediction in this study. SWAT-CUP program is capable of performing sensitivity analysis, calibration, validation, and uncertainty analysis of the SWAT Model (Abbaspour 2015). Besides, to predict the parameters about streamflow and sediment yield, the Sequential Uncertainty Fitting Version 2 (SUFI-2) algorithm was selected (Abbaspour et al. 2004). Two statistical parameters as p-factor and r- 
factor were used in the SUFI-2 algorithm. p-factor (range 0-1) is the percentage of the actual data covered 95PPU (95\% prediction uncertainty). In other words, (1- p-factor) can be defined as a model error (Abbaspour et al. 2017). The r-factor (range $0-\infty$ ) is the ratio of average thickness of 95PPU to standard deviation of observed data. The results having higher p-factor and lower r-factor represent better model performance (Abbaspour et al. 2007).

In sensitivity analysis, $\mathrm{p}$-value and t-stat statistical parameters are used to assess sensitive parameters in the SUFI-2 algorithm. While the p-value approaching zero and larger absolute t-stat values are considered more sensitive the parameters that entered to SWAT-CUP. In this study, the Latin Hypercube One Factor-At-a Time (LH-OAT) (van Griensven and Meixner 2006) sampling technique was used to perform global sensitivity analysis. The SWAT-CUP model was performed with 500 simulations with 25 parameters. 15 most sensitive parameters were selected for streamflow and 13 for sediment yield for calibration and validation procedure both daily and monthly based model (Table 1 and Table 2).

Calibration can be defined as, adjusting model inputs to achieve the best simulation match with observation data. In this study, the parameters which are precipitation lapse rate (PLAPS) and temperature lapse rate (TLAPS) were fixed and removed from the calibration procedure before starting the calibration procedure with the sensitive parameters. Then, the same procedure was applied for the following snow parameters; snowfall temperature (SFTMP), snowmelt base temperature (SMTMP), maximum and minimum melt rate for snow during the year (SMFMX, SMFMN), and snowpack temperature lag factor (TIMP). Finally, the calibration and validation procedure was performed with 500 simulations with chosen sensitive parameters. 
In this study, calibration and validation of the SWAT model were applied with the observed data obtained from two gauging stations (E21A074 and E21A077) on the Murat River basin from 2005-2013. The first year of the period was chosen as a warm-up period. The monthly average discharge and sediment data were used for the monthly based model for selected two gauging stations. Besides, only daily discharge data was used for daily based model. 500 simulations were performed with Nash-Sutcliffe Efficiency (NSE) that was selected as an objective function until reach the satisfactory criteria. After reaching the valid statistical criteria of streamflow estimation, sediment yield can be calibrated and validated because the runoff and streamflow is the main driven factor of sediment transportation (Arnold et al. 2012). After having a satisfactory calibration result from a few iterations, the validation processes should be performed with the same calibrated parameters to simulate streamflow and sediment yield. The average and standard deviation of the streamflow and sediment yield data used in the calibration and validation period should not be much different from each other (Abbaspour et al. 2017). There is a high statistical correlation obtained between calibration and validation data for two gaging stations that are used in this model Table 3.

The results obtained from calibration and validation need to meet some criteria to be called acceptable. Three statistical evaluation criteria were selected to evaluate the performance of the SWAT model based on the accuracy of predicted and observed streamflow and sediment yield. 
(1) The coefficient of determination $\left(\mathrm{R}^{2}\right)$ : It can be defined as how strong the linear relationship is between observed and simulated data (Eq.4). The range of $\mathrm{R}^{2}$ is between 0 to 1 , with higher values indicating better model performance.

$$
R^{2}=\frac{\left[\sum_{i-1}^{n}\left(Q_{s i m}-\overline{Q_{s l m}}\right) *\left(Q_{o b s}-\overline{Q_{o b s}}\right]^{2}\right.}{\sum_{i-1}^{n}\left(Q_{s i m}-\overline{Q_{s l m}}\right)^{2} * \sum_{i-1}^{n}\left(Q_{o b s}-\overline{Q_{o b s}}\right)^{2}}
$$

(2) Nash-Sutcliffe Efficiency (NSE): The NSE specify that how well the plot of observed data versus simulated data fits the 1:1 line (Eq.5). NSE values varies from 0 to 1 while higher values represent more accurate performance (Nash and Sutcliffe 1970).

$$
N S E=1-\frac{\sum_{i-1}^{n}\left(Q_{o b s}-Q_{s i m}\right)^{2}}{\sum_{i-1}^{n}\left(Q_{o b s}-\overline{Q_{o b s}}\right)^{2}}
$$

(3) Percent bias (PBIAS): calculates the percent deviation between observed and simulated data (Eq.6). The best value of PBIAS is zero \%. A negative PBIAS represent that observed values are lower than simulated value. In other words, the model is overestimated (Gupta et al. 1999).

$$
P B I A S=\frac{\sum_{i=1}^{n}\left(Q_{o b s}-Q_{s i m}\right) * 100}{\sum_{i=1}^{n} Q_{o b s}}
$$

Where, $Q_{o b s}$ is the observed value, $\overline{Q_{o b s}}$ is the mean observed value, $Q_{s i m}$ is the simulated value, $\overline{Q_{s i m}}$ is the mean simulated value.

\section{RESULTS AND DISCUSSION}

\subsection{Streamflow outputs}

The created SWAT model was calibrated and validated for streamflow and sediment

yield on monthly and daily basis. Figure 3 indicates the hydrograph of observed and 
simulated streamflow that was obtained from calibration and validation for the monthly and daily basis models for the two gaging stations. The performance criteria including NSE values were found as 0.71 and $0.77, \mathrm{R}^{2}: 0.72$, and 0.79 and PBIAS: $-11.6,-9.1$ in calibration and validation period, respectively at the station E21A077 for the model that monthly time interval. The model uncertainties, $\mathrm{p}$-factor was found as 0.93 and 0.92 while the r-factor, 1.18 and 1.19. According to the (Abbaspour 2022) the obtained results of p-factor and r-factor are quite applicable (Table 4).

However, for the station E21A074, the NSE were found 0.53 and $0.69, \mathrm{R}^{2}, 0.61$ and 0.70 , and PBIAS, -20.1 and 5.2. According to the evaluation criteria by Moriasi et al. (2007), the performance of the model is in the acceptable range for the studied watershed (Table 5). The same procedures were applied to the daily-based simulation. The model produced less successful performance values from the daily simulation than the monthly simulation. Similar results were found in the literature as well (Yang et al. 2016; Duru et al. 2018). However, the results are still in the acceptable ranges with 0.56 and 0.55 NSE, 0.57 and 0.56 $\mathrm{R}^{2},-15$ and 1.2 PBIAS in calibration and validation period at the station E21A074. The detailed results of calibrated and validated streamflow for two stations are given in Table 6.

The scatterplot was created between observed versus simulated streamflow to define the correlation (Fig. 4). 63\% and 74\% correlation values were calculated between observed and simulated streamflow for monthly based simulation while 57\% and $47 \%$ correlation for daily based simulation at the stations E21A074 and E21A077, respectively. 


\subsection{Sediment Yield Outputs}

After the calibrated and validated streamflow prediction performance between acceptable ranges, calibration and validation were computed for the sediment yield estimation based on monthly time intervals at selected two stations. The following simulated monthly sediment

yield for the statistic parameters were found at the station E21A074: NSE as 0.75, 0.8, $\mathrm{R}^{2}$ : 0.76, 0,84, PBIAS: $-0.9,12.2$, p-factor: $0.96,0.75$ and r-factor: $1.90,1,76$ at the calibration and validation period respectively (Table 7). Results show that sediment simulation was well performed at station E21A074. However, the model did not produce good performance criteria at the station E21A077 with the values of NSE: $0.17,0.06, \mathrm{R}^{2}$ : $0.52,0.46$, PBIAS: 69.1, 76.7, p-factor: $0.47,0.42$ and r-factor: $0.26,0.18$ at the calibration and validation period respectively. The observed sediment value was overestimated at station E21A077 as shown in Fig. 5. This could results from observational data error, human interaction such as mining and quarry on the watershed (Daramola et al. 2019). There are many quarries and concreate stations observed in the upper part of the watershed. These findings can explain the easier transport of sediment particles with runoff into the stream that is not captured by the model.

According to the recent study (Abbaspour 2022), the model performance should not be evaluated unsatisfactorily $(\mathrm{NSE}<0.5)$ with only the deterministic case of NSE. The uncertainties analysis (p-factor and r-factor) should be also taken into account. In other words, the model that meets the performance criteria (NSE $>0.5)$ are purposeless if the model uncertainties are not provided (Table 4). Even the model is not in acceptable ranges for the model performance evaluation criteria $(\mathrm{NSE}<0.5)$ at the station E21A077, uncertainty criteria were met with p-factor 0.47 and $0.42>0.4$, r-factor 0.26 and $0.18<2$ for the calibration and 
validation period, respectively. The scatterplot of observed and simulated sediment load data is shown in Fig. 6. The correlation was found $49 \%$ and $79 \%$ between observed and simulated sediment load data at stations E21A077 and E21A074 respectively.

\subsection{Examination of the SWAT Model results}

The results obtained from the SWAT model were accepted as satisfactory for simulating streamflow and sediment yield. This study also investigates the soil erosion prone areas at the sub-basin scale that is important for water management practices with the SWAT model. Some management practices could be applied in the basin to reduce the impact of soil erosion. The soil erosion was divided into five classes: very slight $\left(<1\right.$ tha $\left.^{-1} \mathrm{y}^{-1}\right)$, slight $\left(1-5\right.$ tha $\left.^{-1} \mathrm{y}^{-1}\right)$, moderate $\left(5-10\right.$ tha $\left.^{-1} \mathrm{y}^{-1}\right)$, severe $\left(10-20\right.$ tha $\left.^{-1} \mathrm{y}^{-1}\right)$ and very severe $\left(>20\right.$ tha $\left.^{-1} \mathrm{y}^{-1}\right)$, based on the General Directorate Combating Desertification and Erosion (CEM 2018). The relationship between rainfall, runoff, and sediment yield have been described in Fig. 7 showing that the rainfall, runoff, and sediment yield had the highest value during the wet period of the watershed from March to May, whereas the peaks were observed in April for all parameters. It can be assumed that rainfall and runoff could be driven factors for sediment yield as seen in their trend from Fig. 7.

The sediment delivery ratio can be estimated by some empirical equations. (Boyce 1975; Renfro 1975; Williams and Berndt 1972). Definition of SDR at sub-watershed scale will help to minimize the sediment yield by taking a precaution in the watershed. In this study, SDR was calculated with monthly sediment yield and soil erosion data obtained from SWAT Model (Fig 8). The value of SDR varied from 0.086 to 0.181 , while the lowest value occurred in April and the highest in February. This much variation could depend on differences in the 
size of sub-watershed, land use, slope, and soil texture characteristics. The SDR value is more in the sub-watershed which has a steep slope (sub-watershed 73, 112, 64, 11 etc). That means mentioned sub-watersheds above transport more sediment load to the watershed stream. Low values of SDR are indicated in the sub-watersheds such as 12, 24, 104, 19 where the slope is gentle and the area is small (Fig. 9a).

The yearly average sediment yield for the watershed was found as $14.87 \mathrm{th}^{-1} \mathrm{y}^{-1}$ whereas the highest value of sediment yield was $1044 \mathrm{th}^{-1}$ at the sub-watershed 73 where the steep slope and barren land. Sediment yield occurred in the month of April 2011 while the rainfall and surface runoff was high. In order to prioritize the sediment yield at the sub-watershed scale, the values of sediment yield were classified and illustrated in Fig. 9b.

Soil erosion is a crucial factor in watershed management. A total of $32 \%$ of soil erosion in the watershed was classified as severe erosion, while $21 \%$ moderate, $34 \%$ slight, and $13 \%$ very slight (Fig. 9c). The yearly average soil erosion in the studied watershed was calculated $5.25 \mathrm{th}^{-1} \mathrm{y}^{-1}$. The yearly maximum soil loss was found as $13.74 \mathrm{th}^{-1} \mathrm{y}^{-1}$ at the sub-watershed 137 , with the combination of barren land and areas with a steep slope greater than $25 \%$. These results suggest that the maximum sediment yield and soil loss occur on the watershed with a steep slope and non-agricultural land such as barren and pasture. Since there are many subwatershed-based factors affecting soil losses such as land use/cover, soil type, and slope, Fig. 10 was created to see these effects on soil erosion.

Runoff is one of the main factors that produce sediment yield. The maximum runoff was observed at the sub-watershed 137, with $58.2 \mathrm{~mm}$, and the next sub-watershed 76 with 57.9 $\mathrm{mm}$. The maximum average sediment yield was also obtained at the sub-watershed 76 . It is seen from Fig. 9d. that generally, sediment yield value is high in the sub-watersheds where 
the runoff is high. Fig. 10a. indicates that, a total of $85 \%$ of the barren area on the watershed was under the severe (38\%) and very severe (47\%) soil erosion class whereas the pasture land value was $21 \%$ severe and $4 \%$ very severe condition. $87 \%$ of the total agricultural area produces slight and very slight soil erosion. These results show that the lowest soil erosion occurred in the agricultural area while the highest was seen in the barren area. The reason for that, is the soil particles stay together with the help of the root of the plant and make that are hard to transport by the effect of wind or runoff in the agricultural area.

Fig. 10b shows the ratio of soil erosion for the different soil types on the watershed. $84 \%$ of the watershed was found as a loam soil texture and $30 \%$ of its under the severe (17\%) and very severe (13\%) soil erosion classes. The rest of the watershed $(16 \%)$ is a clay-loam texture with severe (29\%) and very severe (10\%) soil erosion classes. It is expected in Fig. 10c that a higher value of slope produces more soil loss. $21 \%$ of the total area of the basin has a slope of greater than $25 \%$, while $87 \%$ of its under the severe $(38 \%)$ and very severe $(49 \%)$ soil erosion class. With all these findings from the figures, soil erosion is quite dependent on land use, soil type, and soil changes.

\section{Conclusions}

This study tried to demonstrate the usability of the SWAT model for estimating streamflow and sediment yield in the Murat River basin, which is a part of the EuphratesTigris basin, the largest basin in Turkey. The spatial distribution of soil erosion at the subwatershed scale was also analyzed. Several good inferences were obtained from this study to help decision-makers who study in this and nearby watersheds for water management practices. Because of the limited studies about the SWAT model on this watershed this study 
will help researchers and hydrologists who will work in the Murat River basin. The model should be performed with more accurate data entered into the model such as daily sediment and streamflow to obtain and should be used with more monitoring points that help the compare results for further analysis.

\section{Acknowledgements}

This paper has been derived from the doctoral dissertation of Erkan Karakoyun.

Author Contributions Conceptualization, Methodology, Software, Writing first draft:

E.K. Visualization, Review and Editing. Supervision: N.K.

Funding No funds, grants, or other support was received

\section{Declarations}

Ethical Approval Not applicable

Consent to Participate Not applicable.

Consent for Publication Not applicable.

Conflicts of Interest The authors declare that they have no conflict of interest. 


\section{References}

Abbaspour KC (2015) SWAT-CUP: SWAT Calibration and Uncertainty Programs - A User Manual. Eawag Swiss Fed Inst Aquat Sci Technol.

https://doi.org/10.1007/s00402-009-1032-4

Abbaspour KC (2022) The fallacy in the use of the "best-fit" solution in hydrologic modeling. Sci Total Environ 802:149713. https://doi.org/10.1016/j.scitotenv.2021.149713

Abbaspour KC, Johnson CA, van Genuchten MT (2004) Estimating Uncertain Flow and Transport Parameters Using a Sequential Uncertainty Fitting Procedure. Vadose Zo J 3:1340-1352. https://doi.org/10.2113/3.4.1340

Abbaspour KC, Vaghefi SA, Srinivasan R (2017) A guideline for successful calibration and uncertainty analysis for soil and water assessment: A review of papers from the 2016 international SWAT conference. Water (Switzerland) 10:. https://doi.org/10.3390/w10010006

Abbaspour KC, Yang J, Maximov I, Siber R, Bogner K, Mieleitner J, Zobrist J, Srinivasan R (2007) Modelling hydrology and water quality in the pre-alpine/alpine Thur watershed using SWAT. J Hydrol 333:413-430. https://doi.org/10.1016/j.jhydrol.2006.09.014

Akiner ME, Akkoyunlu A (2012) Modeling and forecasting river flow rate from the Melen Watershed, Turkey. J Hydrol 456-457:121-129. https://doi.org/10.1016/j.jhydrol.2012.06.031

Alemayehu D, Srinivasan R, Daggupati P (2014) Application of soil and water assessment tool model to estimate sediment yield in Kaw Lake. Am J Environ Sci 10:530-545. https://doi.org/10.3844/ajessp.2014.530.545

Alipour M, Hosseini M (2018) Simulation of surface runoff in Karaj dam basin, Iran. Appl Water Sci 8:1-10. https://doi.org/10.1007/s13201-018-0782-y

Ang R, Oeurng C (2018) Simulating streamflow in an ungauged catchment of Tonlesap Lake Basin in Cambodia using Soil and Water Assessment Tool (SWAT) model. Water Sci 32:89-101. https://doi.org/10.1016/j.wsj.2017.12.002

Arnold, J. G., Srinivisan R., Muttiah, R.S., and Williams J. (1998) Large Area Hydrological Modeling And Assessment Part I: Model Development. J Am Water Resoruces Assoc 34:73-89. https://doi.org/10.1016/S0899-9007(00)00483-4

Arnold JG, Kiniry JR, Srinivasan R, Williams JR, Haney EB, Neitsch SL (2012) Soil \& Water Assessment Tool, Input/Output Documentation Version 2012, Texas Water Resources Institute

Ayele GT, Teshale EZ, Yu B, Rutherfurd ID, Jeong J (2017) Streamflow and sediment yield prediction for watershed prioritization in the upper Blue Nile river basin, 
Ethiopia. Water (Switzerland) 9:. https://doi.org/10.3390/w9100782

Beskow S, Mello CR, Norton LD, Curi N, Viola MR, Avanzi JC (2009) Soil erosion prediction in the Grande River Basin, Brazil using distributed modeling. Catena 79:49-59. https://doi.org/10.1016/J.CATENA.2009.05.010

Bokan LT (2015) Simulation of Sediment Yield Using SWAT Model : A case of Kulekhani Watershed. M.S.c. Thesis, Norwegian University of Science and Technology

Boyce RC (1975) Sediment routing with sediment-delivery ratios. In: Present and prospective technology for predicting sediment yields and sources. Proceedings of the sediment-yield workshop, USDA Sedimentation Lab, Oxford, Mississippi, Nov. 2830, U. S. Dept. of Agril., ARS-S-40:61-65

Briak H, Moussadek R, Aboumaria K, Mrabet R (2016) Assessing sediment yield in Kalaya gauged watershed (Northern Morocco) using GIS and SWAT model. Int Soil Water Conserv Res 4:177-185. https://doi.org/10.1016/j.iswcr.2016.08.002

CEM, 2018. Turkiye Su Erezyonu Istatistikleri,. Collesme ve Erezyonla Mucadele Genel Mudurlugu Yayinlari, Technical Report, Ankara

Cuceloglu G, Abbaspour KC, Ozturk I (2017) Assessing the water-resources potential of Istanbul by using a soil and water assessment tool (SWAT) hydrological model. Water (Switzerland) 9:. https://doi.org/10.3390/w9100814

Daramola J, Ekhwan TM, Mokhtar J, et al (2019) Estimating sediment yield at Kaduna watershed, Nigeria using soil and water assessment tool (SWAT) model. Heliyon 5:e2106. https://doi.org/10.1016/j.heliyon.2019.e02106

Duru U, Arabi M, Wohl EE (2018) Modeling stream flow and sediment yield using the SWAT model: a case study of Ankara River basin, Turkey. Phys Geogr 39:264-289. https://doi.org/10.1080/02723646.2017.1342199

Dutta S (2016) Soil erosion, sediment yield and sedimentation of reservoir: a review. Model Earth Syst Environ 2:1-18. https://doi.org/10.1007/s40808-016-0182-y

Dutta S, Sen D (2017) Application of SWAT model for predicting soil erosion and sediment yield. Sustain Water Resour Manag 4:447-468. https://doi.org/10.1007/s40899-017-0127-2

ESRI, 2019., ArcGIS Desktop: Release 10.7., Redlands., CA., Environmental Systems Research Institute

Ezz-Aldeen M, Hassan R, Ali A, et al (2018) Watershed sediment and its effect on storage capacity: Case study of Dokan Dam Reservoir. Water (Switzerland) 10:1-16. https://doi.org/10.3390/w10070858

Gull S, MA A, Dar AM (2017) Prediction of Stream Flow and Sediment Yield of Lolab Watershed Using SWAT Model. Hydrol Curr Res 08: https://doi.org/10.4172/21577587.1000265 
Gupta HV, Sorooshian S, Yapo PO (1999) Status of Automatic Calibration for Hydrologic Models: Comparison with Multilevel Expert Calibration. J Hydrol Eng 4:135-143. https://doi.org/10.1061/(ASCE)1084-0699(1999)4:2(135)

Guzel C (2010) Application Of Swat Model In A Watershed In Turkey. M.S.c. Thesis, Istanbul Technical University

Jakada H, Chen Z (2020) An approach to runoff modelling in small karst watersheds using the SWAT model. Arab J Geosci 13:. https://doi.org/10.1007/s12517-020-05291-0

Jodar-Abellan A, Valdes-Abellan J, Pla C, Gomariz-Castillo F (2019) Impact of land use changes on flash flood prediction using a sub-daily SWAT model in five Mediterranean ungauged watersheds (SE Spain). Sci Total Environ 657:1578-1591. https://doi.org/10.1016/j.scitotenv.2018.12.034

Juracek KE, Stiles TC (2012) The Role Of Reservoir Sediment Studies In The Tmdl Process In Kansas. Proc Water Environ Fed 2003:1091-1102. https://doi.org/10.2175/193864703784828273

Mahmood K (1987) Reservoir Sedimentation: Impact, Extent, Mitigation. World Bank Tech. Rep. 71, Washington DC.

Moriasi DN, Arnold JG, Van Liew MW, Bingner RL, Harmel RD, Veith TL (2007) Model Evaluation Guidelines For Systematic Quantification Of Accuracy In Watershed Simulations. Trans ASABE 2007 50:885-900. https://doi.org/10.1234/590

Morris GL, Fan J (1998) Reservoir sedimentation handbook. Tata McGraw-Hill Publishing Company, New York.

Mutchler CK, Murphree CE, McGregor KC (1988) Laboratory and field plots for soil erosion studies. Soil erosion research methods., 9-36.

NASA/METI/AIST/Japan Spacesystems and U.S./Japan ASTER Science Team (2019) ASTER Global Digital Elevation Model V003 [Data set]. NASA EOSDIS Land Processes DAAC. Avaible online: https://lpdaac.usgs.gov/products/astgtmv003/ (accessed 25 October 2020)

Nash JE, Sutcliffe JV (1970) River flow forecasting through conceptual models part I - A discussion of principles. J Hydrol 10:282-290. https://doi.org/10.1016/00221694(70)90255-6

Neitsch SL, Arnold JG, Kiniry JR, Williams JR (2005) Soil And Water Assessment Tool Theoretical Documentation Version 2005. Grassland, Soil And Water Research Laboratory, Agricultural Research Service, Blackland Research Center, Texas Agricultural Experiment Station

Ouyang D, Bartholic J (1997) Predicting sediment delivery ratio in Saginaw Bay watershed. 22nd National Association of Environmental Professionals Conference Proceedings. 19-23 May 1997, Orlando, pp 659-671 
Ouyang D, Bartholic J (2005) Predicting Sediment Delivery Ratio In Sagınaw Bay Watershed, Ins. Of Water Research, Michigan. Avaible online: http://www.iwr.msu.edu/rusle/sdr/sag-sdr.htm. (Accessed 13 August 2021)

Panda C, Das DM, Raul SK, Sahoo BC (2021) Sediment yield prediction and prioritization of sub-watersheds in the Upper Subarnarekha basin (India) using SWAT. Arab J Geosci 14:. https://doi.org/10.1007/s12517-021-07170-8

Peker IB, Sorman AA (2021) Application of SWAT using snow data and detecting climate change impacts in the mountainous eastern regions of Turkey. Water (Switzerland) 13:. https://doi.org/10.3390/w13141982

Pimentel D, Harvey C, Resosudarmo P, Sinclair K, Kurz D, McNair M, Crist S, Shpritz L, Fitton L, Saffouri R, Blair R (1995) Environmental and Economic Costs of Soil Erosion and Conservation Benefits. Science (80- ) 267:1117-1123. https://doi.org/10.1126/SCIENCE.267.5201.1117

Portenga EW, Bierman PR (2011) Understanding earth's eroding surface with 10Be. GSA Today 21:4-10. https://doi.org/10.1130/G111A.1

Renfro GW (1975) Use of erosion equations and sediment delivery ratios for predicting sediment yield. Present and Prospective Technology for Predicting Sediment Yields and Sources, US Department of Agriculture Publication ARS-S-40, pp 33-45

Qi J, Zhang X, Yang Q, Srinivasan R, Arnold JG, Li J, Waldholf ST, Cole J. (2020) SWAT ungauged: Water quality modeling in the Upper Mississippi River Basin. J Hydrol 584:. https://doi.org/10.1016/j.jhydrol.2020.124601

Rodríguez-Blanco ML, Arias R, Taboada-Castro MM, Nunes JP, Keizer JJ, TaboadaCastro, MT (2016) Sediment Yield at Catchment Scale Using the SWAT (Soil and Water Assessment Tool) Model. Soil Sci 181:. https://doi.org/10.1097/SS.0000000000000158

Runkel RL, Crawford CG, Cohn TA Load Estimator (LOADEST): A FORTRAN Program for Estimating Constituent Loads in Streams and Rivers

Tesema TA, Leta OT (2020) Sediment Yield Estimation and Effect of Management Options on Sediment Yield of Kesem Dam Watershed, Awash Basin, Ethiopia. Sci African 9:e00425. https://doi.org/10.1016/j.sciaf.2020.e00425

van Griensven A, Meixner T (2006) Methods to quantify and identify the sources of uncertainty for river basin water quality models. Water Sci Technol 53:51-59. https://doi.org/10.2166/WST.2006.007

Van Liew MW, Mittelstet AR (2018) Comparison of three regionalization techniques for predicting streamflow in ungaged watersheds in nebraska, USA using SWAT model. Int J Agric Biol Eng 11:110-119. https://doi.org/10.25165/j.ijabe.20181103.3528

Vigiak O, Malagó A, Bouraoui F, Vanmaercke M, Poesen J (2015) Adapting SWAT hillslope erosion model to predict sediment concentrations and yields in large Basins. 
Sci Total Environ 538:855-875. https://doi.org/10.1016/j.scitotenv.2015.08.095

Walling DE (1983) The sediment delivery problem. J Hydrol 65:209-237. https://doi.org/10.1016/0022-1694(83)90217-2

Williams JR (1975) Sediment-yield prediction with Universal Equation using runoff energy factor. In: Present and Prospective Technology for Predicting Sediment Yield and Sources, US Department of Agriculture, Agriculture Research Service, Washington DC, 244-252

Williams, J.R., Berndt, H.D., 1972. Sediment yield computed with universal equation. J Hydraul Div 98(12):2087-2098

Worku T, Khare D, Tripathi SK (2017) Modeling runoff-sediment response to land use/land cover changes using integrated GIS and SWAT model in the Beressa watershed. Environ Earth Sci 76:1-15. https://doi.org/10.1007/s12665-017-6883-3

Wu Y, Chen J (2012) Modeling of soil erosion and sediment transport in the East River Basin in southern China. Sci Total Environ 441:159-168. https://doi.org/10.1016/J.SCITOTENV.2012.09.057

Xu ZX, Pang JP, Liu CM, Li JY (2009) Assessment of runoff and sediment yield in the miyun reservoir catchment by using SWAT model. Hydrol Process. https://doi.org/10.1002/hyp.7475

Yang X, Liu Q, He Y, Luo X, Zhang X (2016) Comparison of daily and sub-daily SWAT models for daily streamflow simulation in the Upper Huai River Basin of China. Stoch Environ Res Risk Assess 30:959-972. https://doi.org/10.1007/s00477-015-1099-0

Yıldırımer S (2018) Borçka Baraji Havzasinda Su Rejimi, Su Kalitesi ve Sediment Veriminin Swat Kullanarak Belirlenmesi ve Modellenmesi. Dissertation, Artvin Coruh University

Zare M, Panagopoulos T, Loures L (2017) Simulating the impacts of future land use change on soil erosion in the Kasilian watershed, Iran. Land use policy 67:558-572. https://doi.org/10.1016/J.Landusepol.2017.06.028

Zhang X, Xu YP, Fu G (2014) Uncertainties in SWAT extreme flow simulation under climate change. J Hydrol 515:205-222. https://doi.org/10.1016/j.jhydrol.2014.04.064 


\section{Figure Legends}

Fig. 1 Location map of Murat River basin

Fig. 2 (a) Topographic map and location of climate station on the watershed, (b) Land use/cover area classification, (c) soil types classification, (d) slope classification of the Murat River Basin

Fig. 3 Monthly observed streamflow versus simulated streamflow at the station E21A074 (a), and E21A077 (b). Daily observed streamflow versus simulated streamflow at the station E21A074 (c), and E21A077 (d)

Fig. 4 Scatterplots of monthly (a) E21A074, (b) E21A077 and daily (c) E21A074 and (d) E21A077 simulated streamflow vs observed streamflow during calibration and validation

Fig. 5 Observed and simulated monthly sediment load at (a) E21A077 and (b) E21A074.

Fig. 6 Scatterplot of monthly simulated versus observed sediment for the stations (a) E21A074, (b) E21A077.

Fig. 7 The monthly patterns of rainfall, runoff and sediment yield

Fig. 8 Comparison of monthly sediment yield vs sediment delivery ratio

Fig. 9 An illustration of sub-watershed scales of (a) SDR, (b) Sediment yield, (c) Soil erosion and (d) surface runoff at study area

Fig. 10 The percantage of the soil erosion by (a) Land Use, (b) Soil type, (c) Terrain slope 


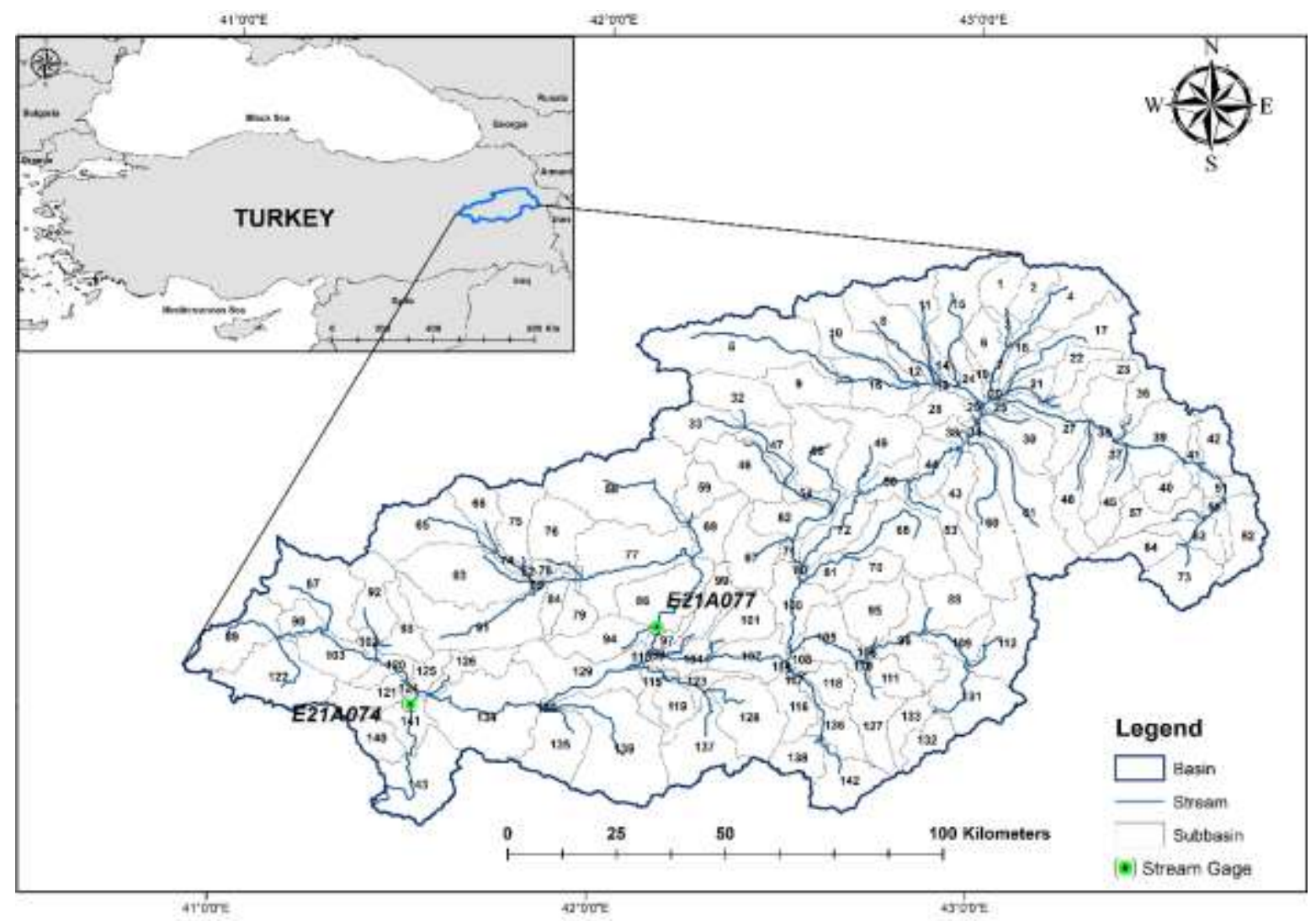

Fig. 1 Location map of Murat River basin 

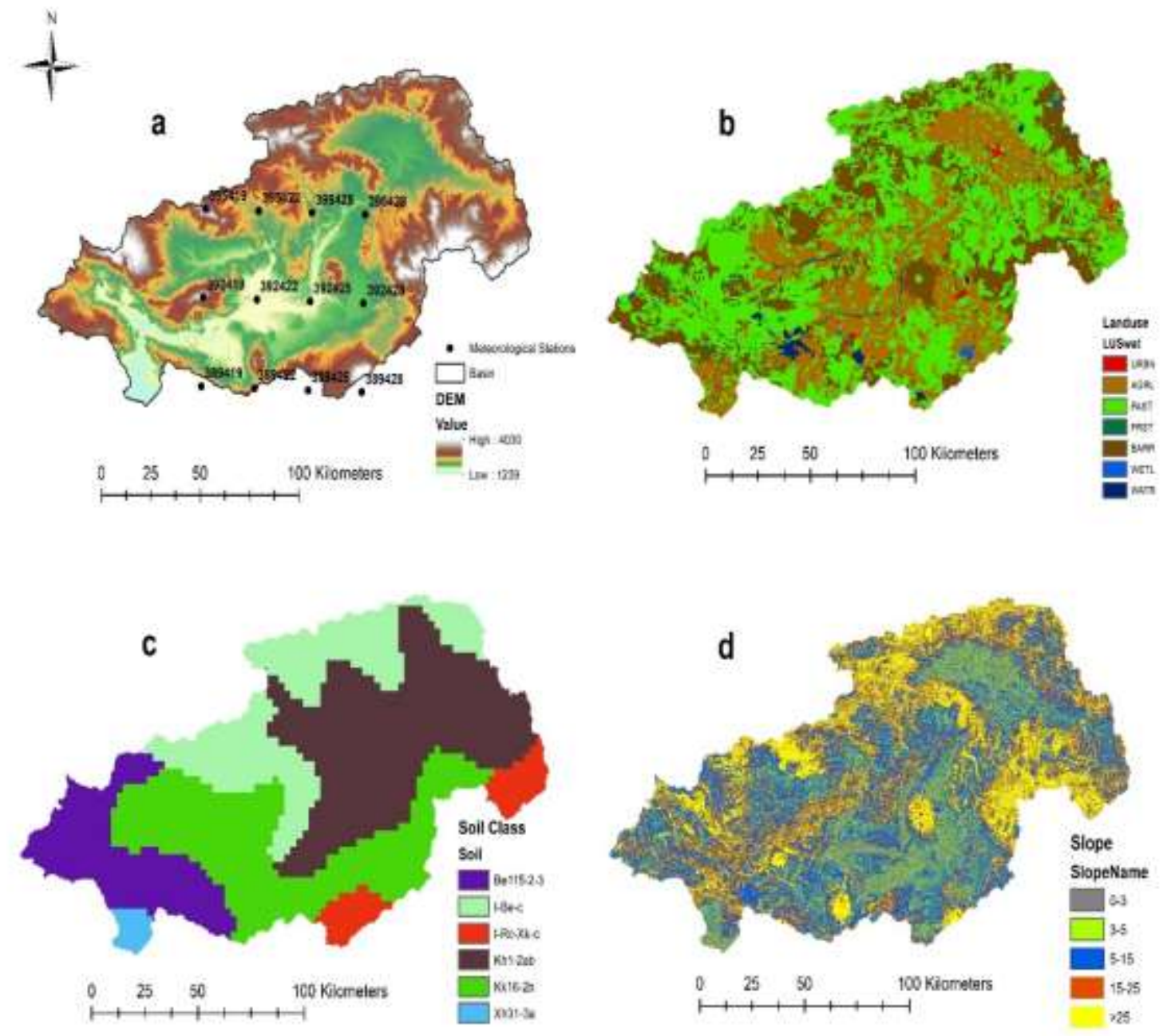

Fig. 2 (a) Topographic map and location of climate station on the watershed, (b) Land use/cover area classification, (c) soil types classification, (d) slope classification of the Murat River Basin. 

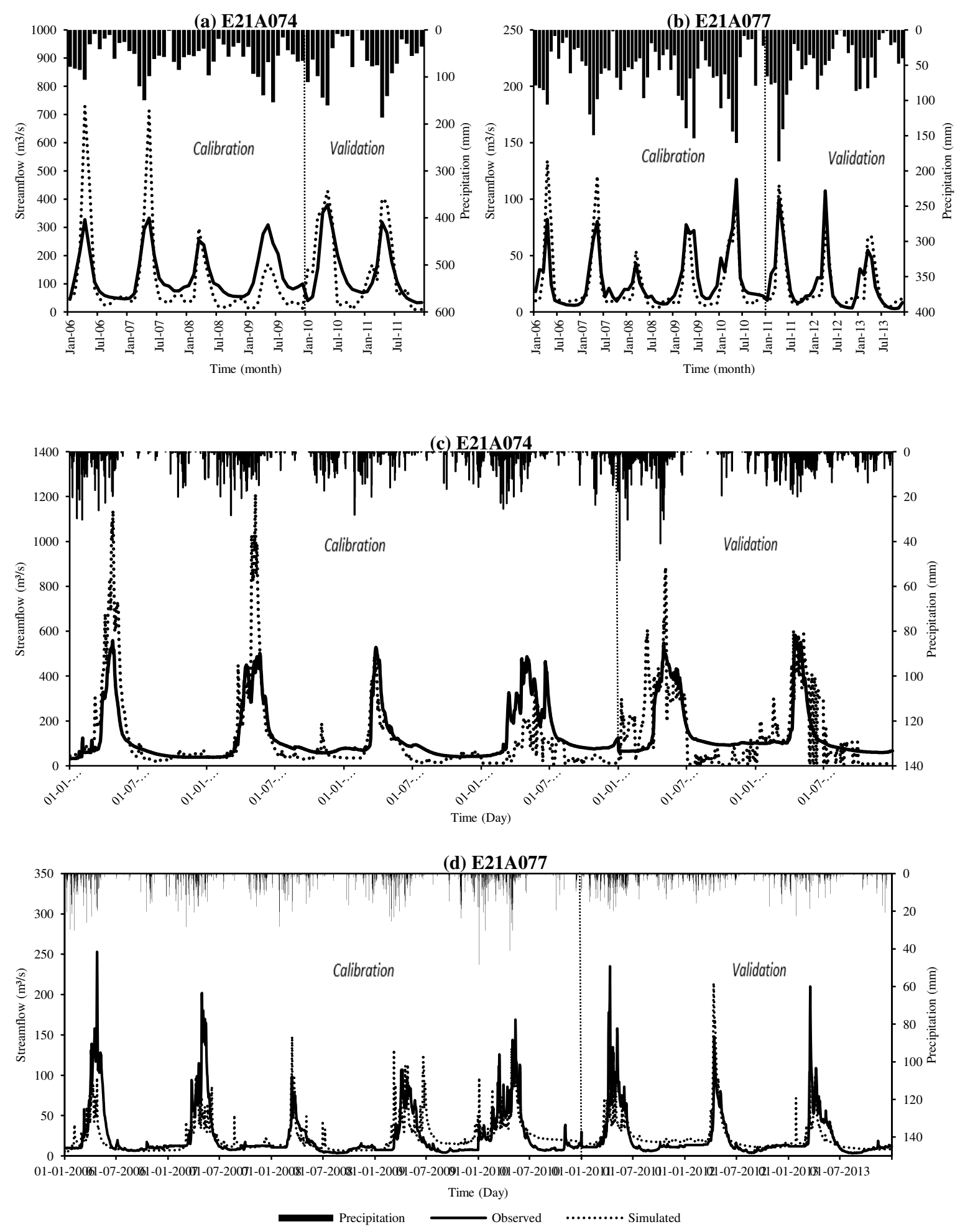

Fig. 3 Monthly observed streamflow versus simulated streamflow at the station E21A074 (a), and E21A077 (b). Daily observed streamflow versus simulated streamflow at the station E21A074 (c), and E21A077 (d). 

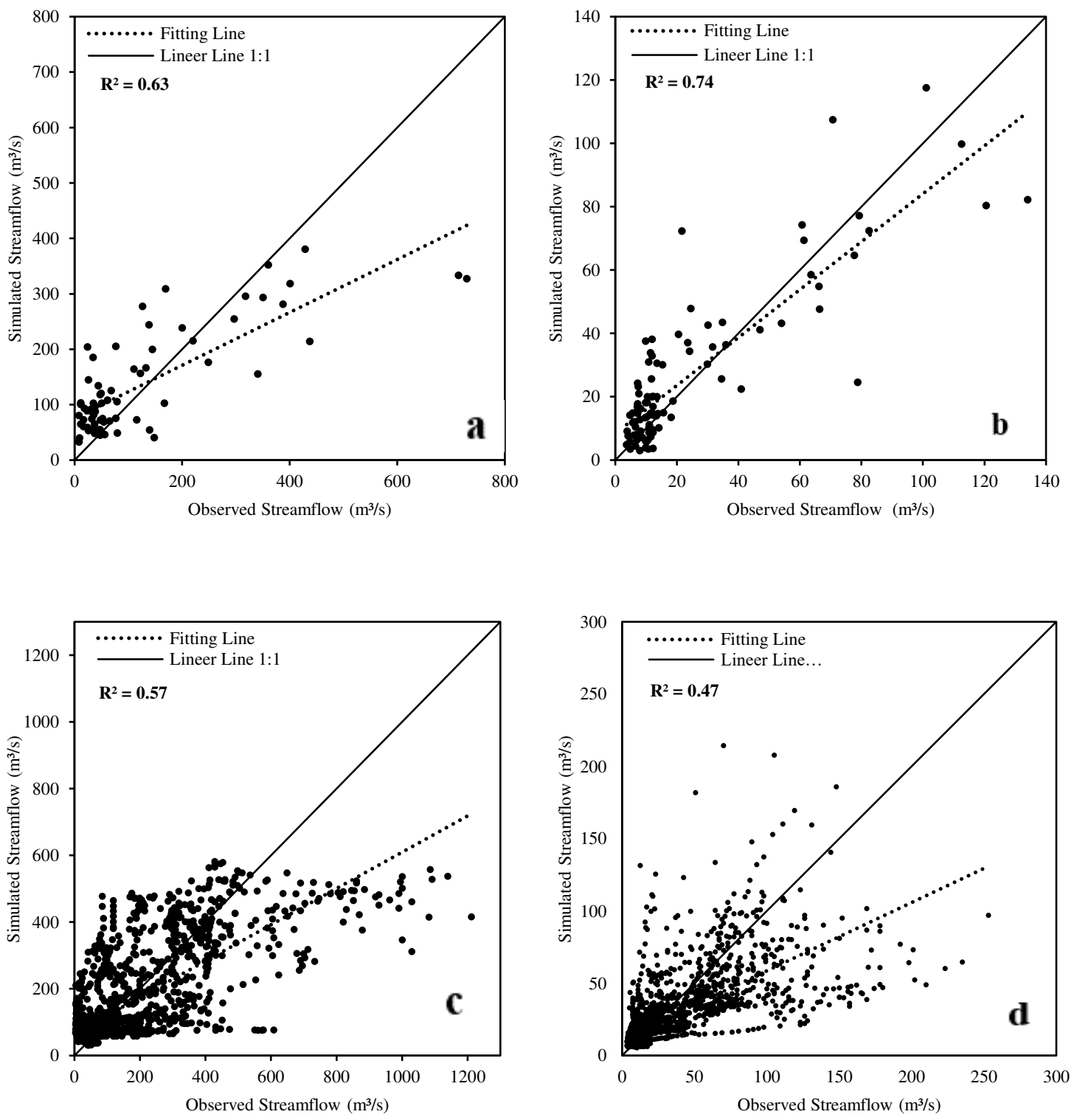

Fig. 4 Scatterplots of monthly (a) E21A074, (b) E21A077 and daily (c) E21A074 and (d) E21A077 simulated streamflow vs observed streamflow during calibration and validation. 

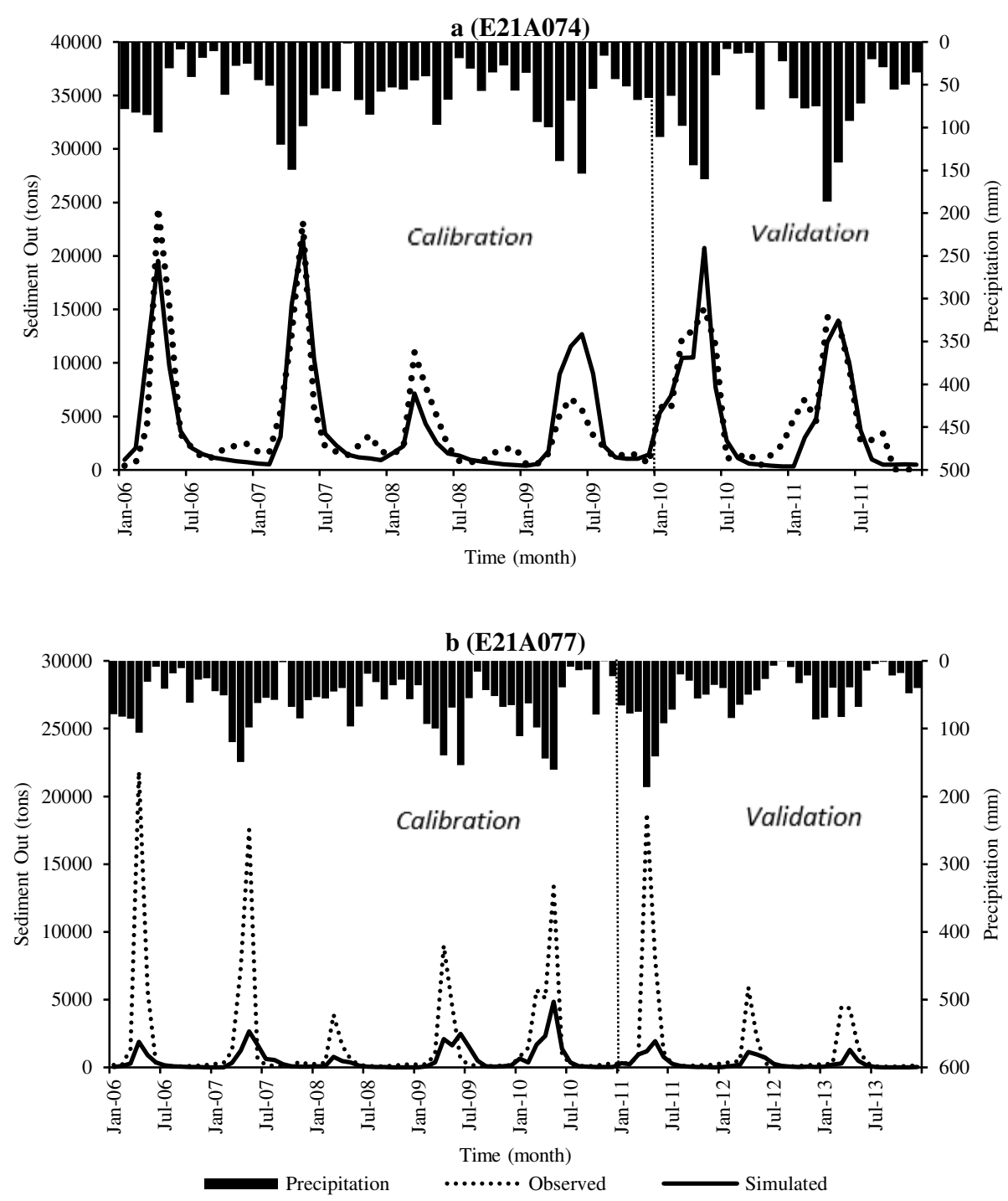

Fig. 5 Observed and simulated monthly sediment load at (a) E21A077 and (b) E21A074. 

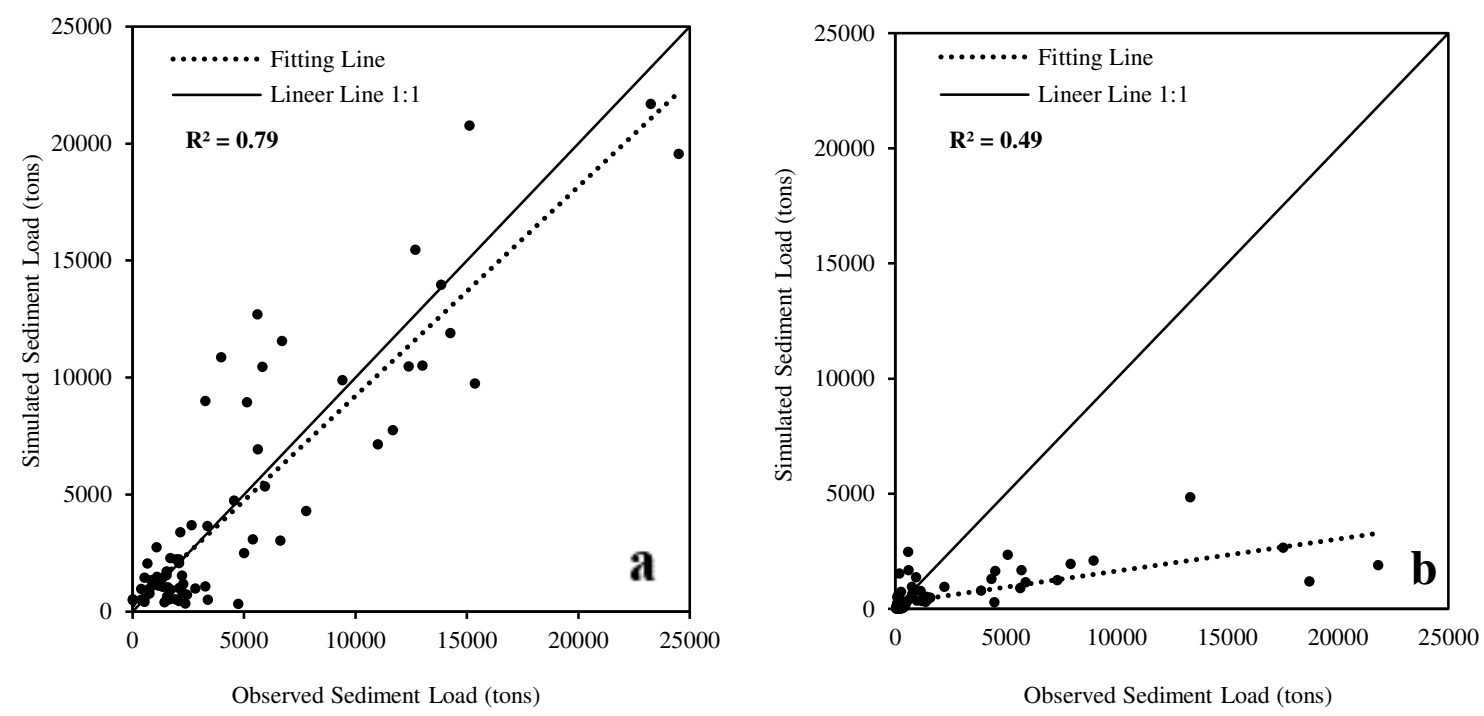

Fig. 6 Scatterplot of monthly simulated versus observed sediment for the stations (a) E21A074, (b) E21A077. 


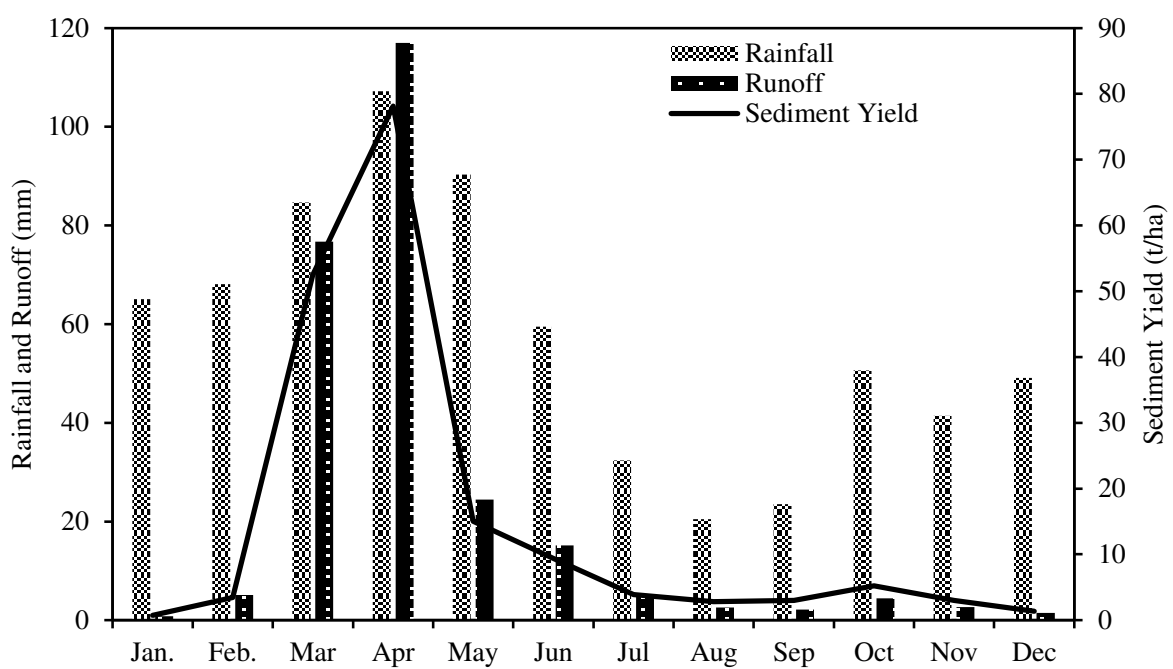

Fig. 7 The monthly patterns of rainfall, runoff and sediment yield

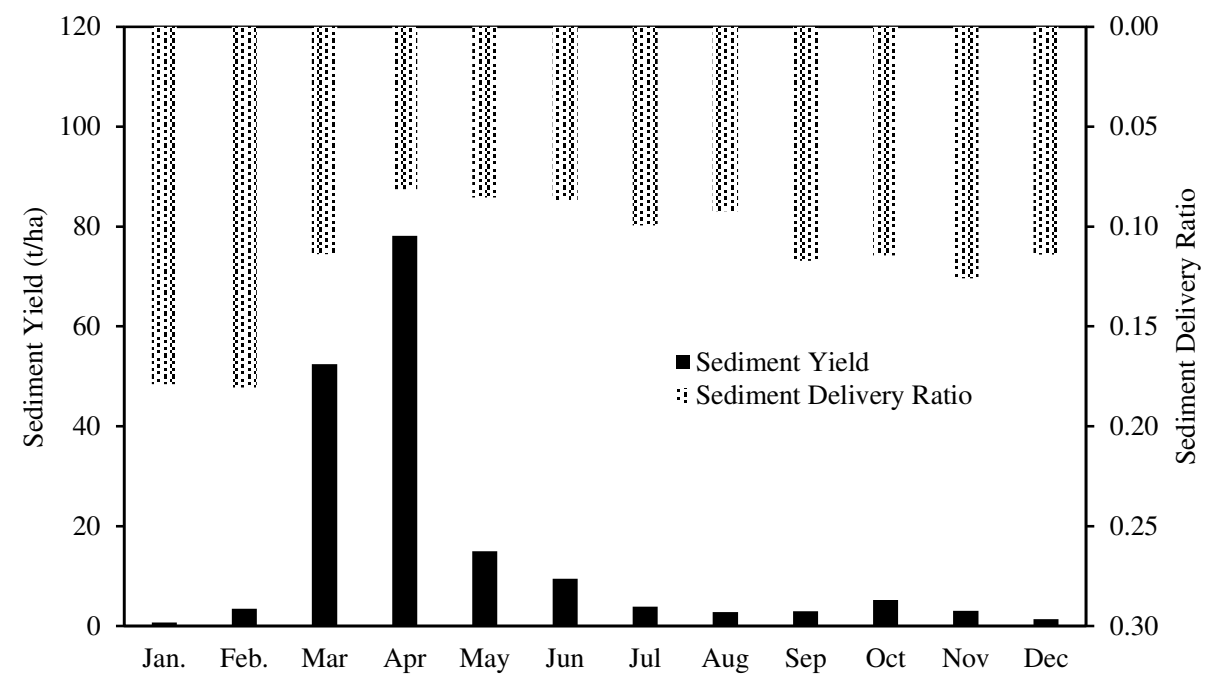

Fig. 8 Comparison of monthly sediment yield vs sediment delivery ratio 

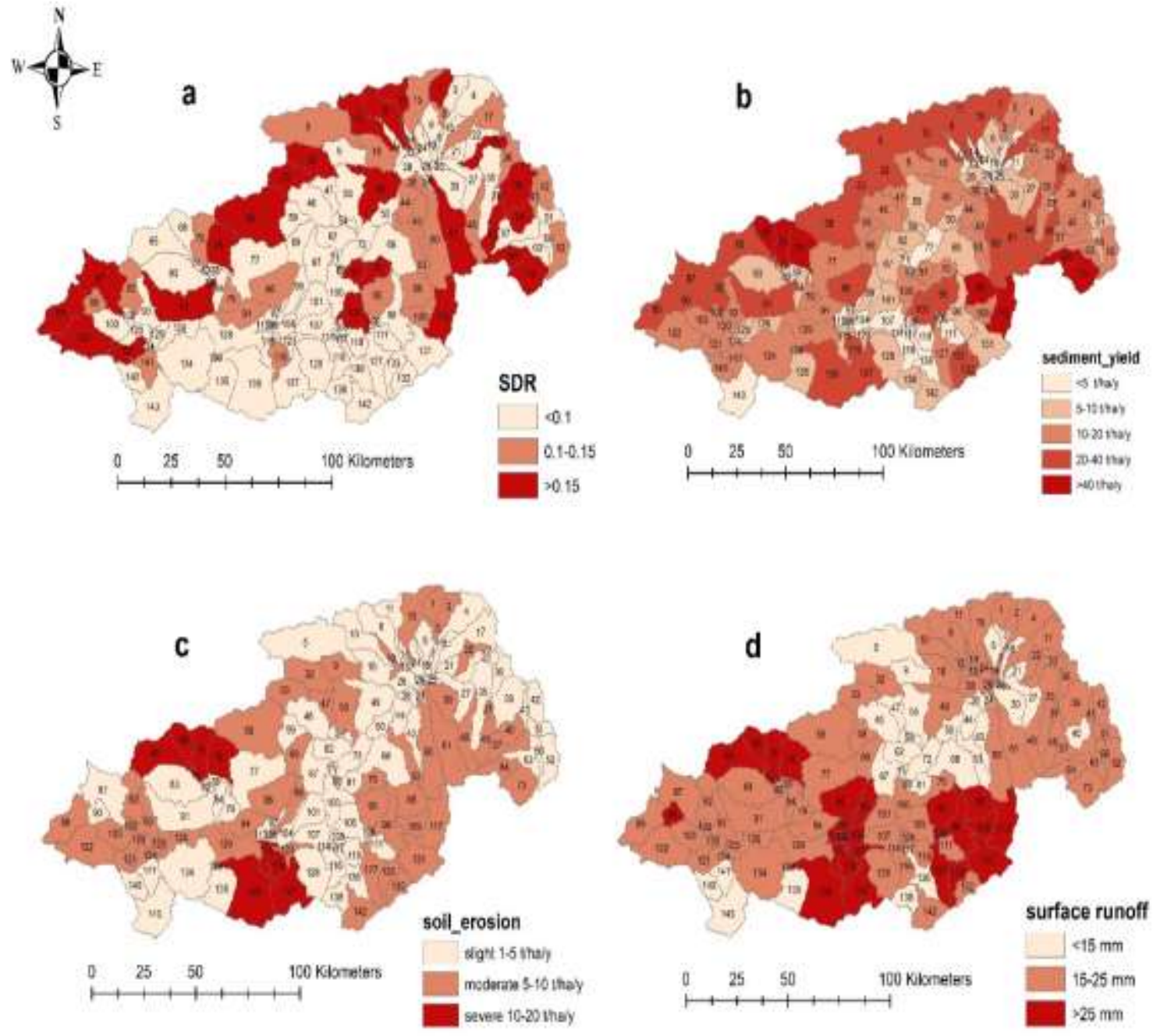

Fig. 9 An illustration of sub-watershed scales of (a) SDR, (b) Sediment yield, (c) Soil erosion and (d) surface runoff at study area 

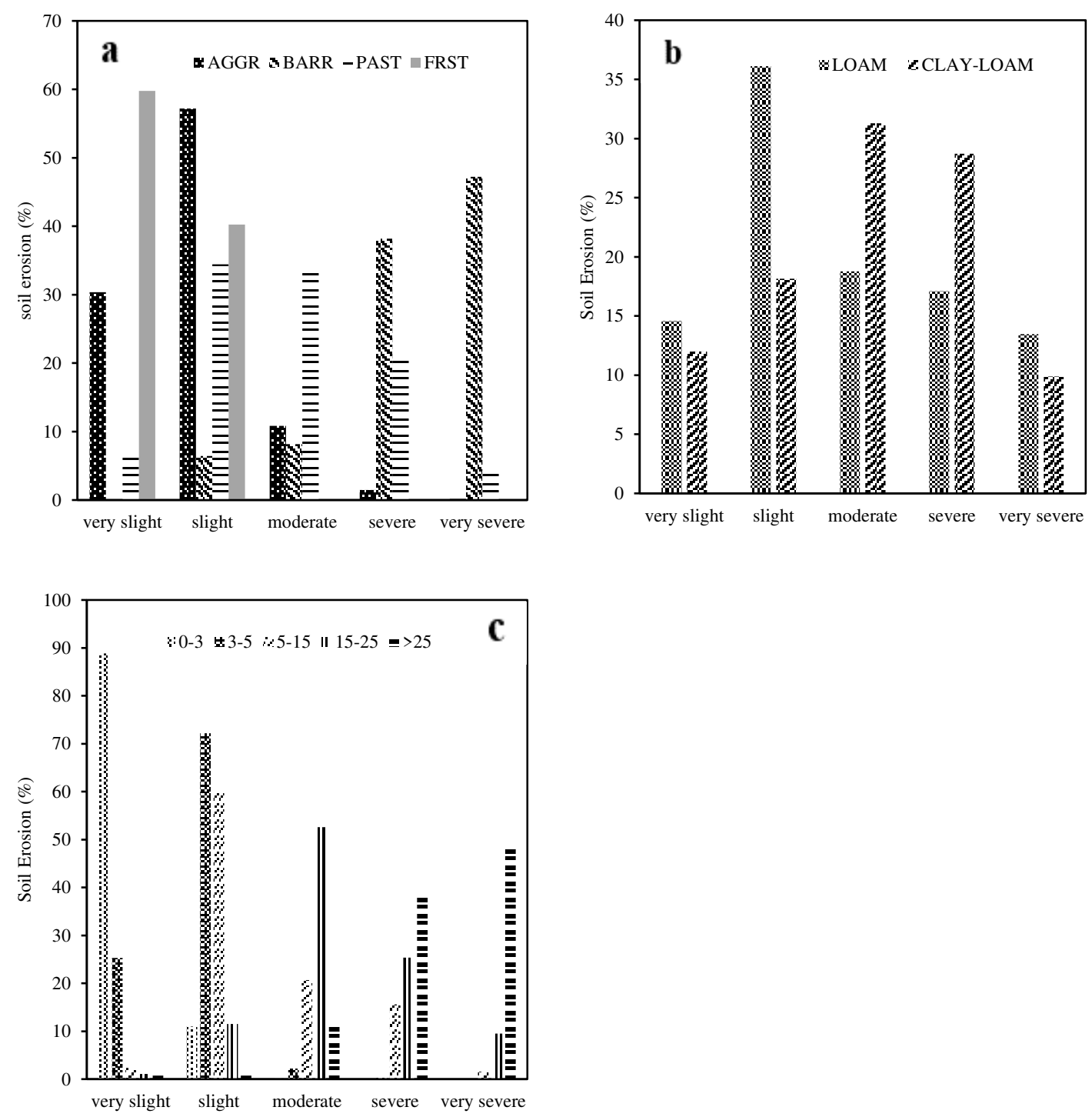

Fig. 10 The percantage of the soil erosion by (a) Land Use, (b) Soil type, (c) Terrain slope 


\section{Table Legends}

Table 1 Sensitive parameters for streamflow simulation and their fitted values

Table 2 Sensitive parameters for sediment simulation and their fitted values

Table 3 Statistical comparison of calibration and validation data of sediment and streamflow

Table 4 The range of uncertainty analysis for streamflow and sediment simulation (Abbaspour 2022)

Table 5 The performance criteria of recommended statistics for streamflow and sediment (Moriasi et al. 2007; Ayele et al. 2017)

Table 6 Performance of the SWAT model for daily and monthly streamflow prediction for the station E21A077 and E21A074

Table 7 Performance of the SWAT model for monthly sediment yield prediction for the station E21A077 and E21A074. 
Table 1 Sensitive parameters for streamflow simulation and their fitted values

\begin{tabular}{|c|c|c|c|}
\hline Rank & Sensitive Parameters & $\begin{array}{l}\text { Initial } \\
\text { Range }\end{array}$ & $\begin{array}{l}\text { Fitted } \\
\text { value }\end{array}$ \\
\hline 1 & r_CN2 (SCS Curve Number) & -0.4 to 0.4 & -0.09 \\
\hline 2 & v_ESCO (Soil evaporation compensation factor) & 0.01 to 1 & 0.46 \\
\hline 3 & v_ALPHA_BF (Baseflow alpha factor) & 0 to 1 & 0.13 \\
\hline 4 & v_CANMX (Maximum canopy storage) & 0 to 100 & 56.12 \\
\hline 5 & $\begin{array}{l}\text { v_CH_K2 (Effective hydraulic conductivity in main channel } \\
\text { alluvium) }\end{array}$ & 0 to 150 & 101.71 \\
\hline 6 & v_OV_N (Manning's "n" value for overland flow) & 0 to 0.8 & 0.24 \\
\hline 7 & v_CH_N2 (Manning's "n" value for the main channel) & 0 to 0.3 & 0.13 \\
\hline 8 & v_RCHRG_DP (Deep aquifer percolation fraction) & 0 to 1 & 0.57 \\
\hline 9 & r_SOL_Z (Depth from soil surface to bottom of layer) & -0.3 to 0.3 & -0.09 \\
\hline 10 & v_GW_DELAY (Groundwater delay) & 0 to 400 & 206.28 \\
\hline 11 & v_EPCO (Plant uptake compensation factor) & 0.01 to 1 & 0.24 \\
\hline 12 & r_SOL_AWC (Available water capacity of the soil layer) & -0.3 to 0.3 & -0.01 \\
\hline 13 & $\begin{array}{l}\text { v_FFCB (Initial soil water storage expressed as a fraction of field } \\
\text { capacity water content) }\end{array}$ & 0 to 1 & 0.56 \\
\hline 14 & v_SURLAG (Surface runoff lag time) & 1 to 24 & 11.74 \\
\hline 15 & v_SLSOIL (Slope length for lateral subsurface flow) & 0 to 150 & 63.13 \\
\hline
\end{tabular}

$\mathrm{v}$ : existing parameter value is to be replaced by a given value

$\mathrm{r}$ : existing parameter value is multiplied by (1+given value) 
Table 2 Sensitive parameters for sediment simulation and their fitted values

\begin{tabular}{clcc}
\hline Rank & Sensitive Parameters & $\begin{array}{c}\text { Initial } \\
\text { Range }\end{array}$ & $\begin{array}{c}\text { Fitted } \\
\text { value }\end{array}$ \\
\hline 1 & r_USLE_K (USLE equation soil erodibility (K) factor) & -0.8 to 0.8 & -0.78 \\
2 & r_CN2 (SCS Curve Number) & -0.4 to 0.4 & -0.38 \\
3 & v_GW_DELAY (Groundwater delay) & 0 to 400 & 61.20 \\
4 & v_ESCO (Soil evaporation compensation factor) & 0.01 to 1 & 0.2 \\
5 & v_EPCO (Plant uptake compensation factor) & 0.01 to 1 & 0.43 \\
6 & v_CH_K2 (Effective hydraulic conductivity in main channel alluvium) & 0 to 150 & 7.35 \\
7 & v_CH_N2 (Manning's "n" value for the main channel) & 0 to 0.3 & 0.15 \\
8 & v_CANMX (Maximum canopy storage) & 0 to 100 & 41.70 \\
9 & r_SOL_Z (Depth from soil surface to bottom of layer) & -0.3 to 0.3 & 0.02 \\
10 & r_SOL_AWC (Available water capacity of the soil layer) & -0.3 to 0.8 & 0.62 \\
11 & v_OV_N (Manning's "n" value for overland flow) & 0 to 1 & 0.37 \\
12 & CH_COV1 (Channel erodibility factor) & -0.05 to 0.6 & 0.17 \\
13 & ADJ_PKR (Peak rate adjustment factor for sediment routing in the & 0.5 to 2 & 0.86 \\
& subbasin) & & \\
\hline
\end{tabular}

v: existing parameter value is to be replaced by a given value r: existing parameter value is multiplied by (1+given value) 
Table 3 Statistical comparison of calibration and validation data of sediment and streamflow

\begin{tabular}{cccccc}
\hline & & \multicolumn{2}{c}{ Sediment } & \multicolumn{2}{c}{ Streamflow } \\
& & Mean & $\begin{array}{c}\text { Standard } \\
\text { Deviation }\end{array}$ & Mean & $\begin{array}{c}\text { Standard } \\
\text { Deviation }\end{array}$ \\
\hline \multirow{2}{*}{ E21A077 } & Calibration & 1855 & 4145 & 24.7 & 29.1 \\
& Validation & 1451 & 3428 & 22.9 & 25.4 \\
\multirow{2}{*}{ E21A074 } & Calibration & 3960 & 5185 & 108 & 155 \\
& Validation & 5595 & 5064 & 149 & 142 \\
\hline
\end{tabular}

Table 4 The range of uncertainty analysis for streamflow and sediment simulation (Abbaspour 2022)

\begin{tabular}{ccc}
\hline Uncertainties & Streamflow & Sediment \\
\hline p-factor & $\geq 0.7$ & $\geq 0.4$ \\
r-factor & $\leq 1.5$ & $\leq 2$ \\
\hline
\end{tabular}

Table 5 The performance criteria of recommended statistics for streamflow and sediment (Moriasi et al. 2007; Ayele et al. 2017)

\begin{tabular}{ccccc}
\hline $\begin{array}{c}\text { Performance } \\
\text { Rating }\end{array}$ & $\mathbf{R}^{2}$ & NSE & Streamflow & Sediment \\
\hline Very good & $0.7<\mathrm{R}^{2}<1$ & $0.75<\mathrm{NSE}<1.00$ & PBIAS $< \pm 10$ & PBIAS $< \pm 15$ \\
Good & $0.6<\mathrm{R}^{2}<0.7$ & $0.65<\mathrm{NSE}<0.75$ & $\pm 10<$ PBIAS $< \pm 15$ & $\pm 15<$ PBIAS $< \pm 30$ \\
Satisfactory & $0.5<\mathrm{R}^{2}<0.6$ & $0.50<\mathrm{NSE}<0.65$ & $\pm 15<$ PBIAS $< \pm 25$ & $\pm 30<$ PBIAS $< \pm 55$ \\
Unsatisfactory & $\mathrm{R}^{2}<0.5$ & $\mathrm{NSE}<0.50$ & PBIAS $> \pm 25$ & PBIAS $> \pm 55$ \\
\hline
\end{tabular}


Table 6 Performance of the SWAT model for daily and monthly streamflow prediction for the station E21A077 and E21A074.

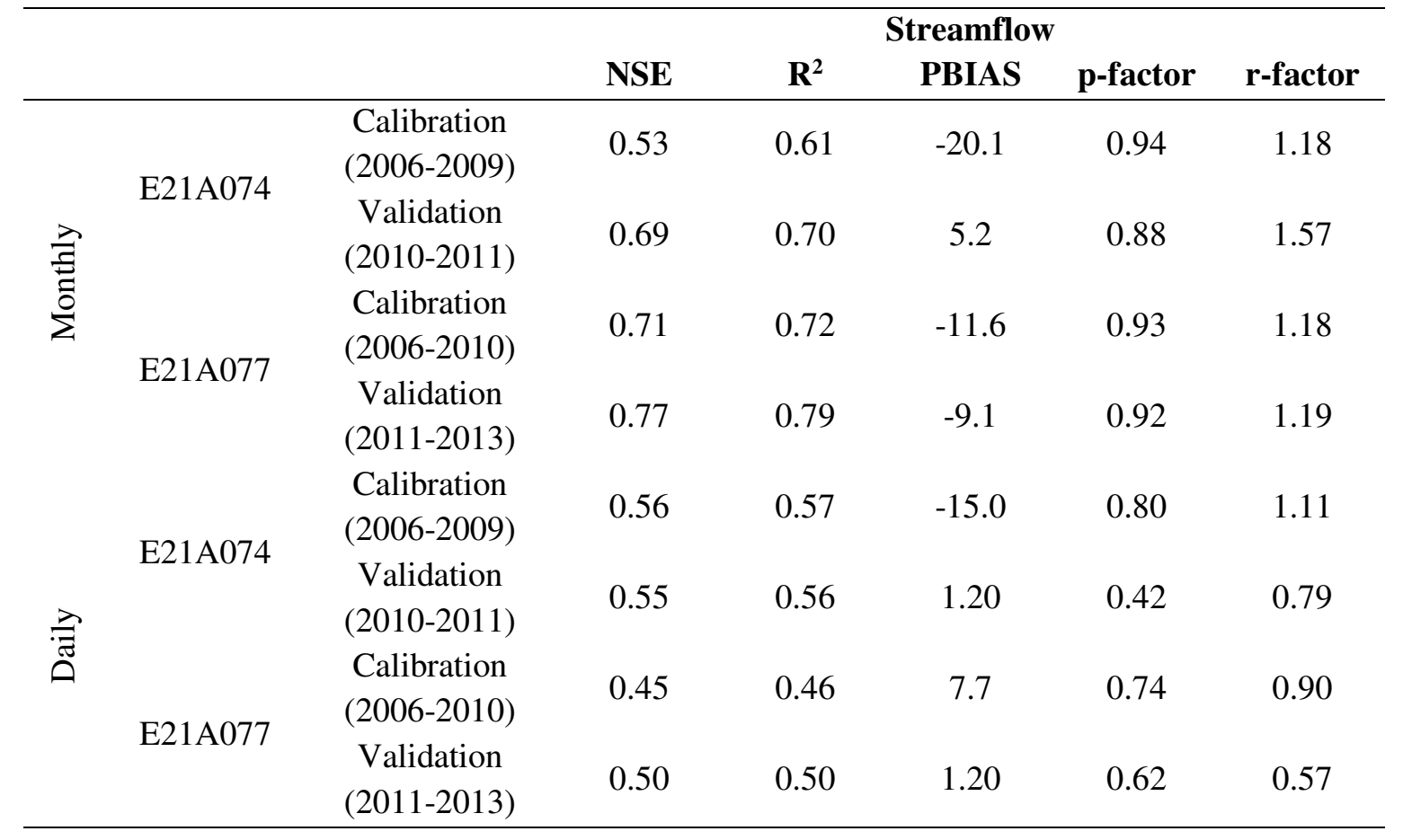

Table 7 Performance of the SWAT model for monthly sediment yield prediction for the station E21A077 and E21A074.

\begin{tabular}{ccccccc}
\hline \multirow{2}{*}{ E21A074 } & NSE & $\mathbf{R}^{2}$ & $\begin{array}{c}\text { Sediment } \\
\text { PBIAS }\end{array}$ & p-factor & r-factor \\
\hline E21A077 & $\begin{array}{c}\text { Calibration } \\
(2006-2009) \\
\text { Validation } \\
\text { (2010-2011) }\end{array}$ & 0.75 & 0.76 & -0.9 & 0.96 & 1.90 \\
& $\begin{array}{c}\text { Calibration } \\
\text { (2006-2010) } \\
\text { Validation } \\
\text { (2011-2013) }\end{array}$ & 0.17 & 0.52 & 69.1 & 0.47 & 0.26 \\
\hline
\end{tabular}




\section{Supplementary Files}

This is a list of supplementary files associated with this preprint. Click to download.

- graphicalabstract.docx 